\title{
Discharge Estimation for an Ungauged Inland River in an Arid Area Related to Anthropogenic Activities: A Case Study of Heihe River Basin, Northwestern China
}

\author{
Shuang Liu, ${ }^{1,2}$ Zhenghui Xie, ${ }^{1}$ and Yujin Zeng ${ }^{1,2}$ \\ ${ }^{1}$ State Key Laboratory of Numerical Modeling for Atmospheric Sciences and Geophysical Fluid Dynamics, \\ Institute of Atmospheric Physics, Chinese Academy of Sciences, Beijing 100029, China \\ ${ }^{2}$ College of Earth Science, University of Chinese Academy of Sciences, Beijing 100049, China
}

Correspondence should be addressed to Zhenghui Xie; zxie@lasg.iap.ac.cn

Received 29 June 2016; Revised 21 September 2016; Accepted 2 November 2016

Academic Editor: Jan Friesen

Copyright (C) 2016 Shuang Liu et al. This is an open access article distributed under the Creative Commons Attribution License, which permits unrestricted use, distribution, and reproduction in any medium, provided the original work is properly cited.

\begin{abstract}
In the arid areas, the discharge in some reaches is unsurveyed, which makes related works trapped. It is important to estimate a longterm discharge in an ungauged river using available fragmentary data including those on human activities. In this work, the authors proposed a procedure of monthly discharge estimation for an ungauged inland river based on spatiotemporally discontinuous information, such as water diversion for irrigation, water allocation planning, and statistical relations of discharge at different locations. A typical ungauged river reach of Heihe River in northwestern China was selected as a case study. Monthly discharge from 1991 to 2007 at one gauged section was estimated using this procedure to validate the procedure, and the results show its potential in estimating discharge for an ungauged area. Monthly discharge from 1979 to 2014 at four unmonitored sections was estimated using the same procedure, and the trend analysis was conducted to check the facticity of the estimated discharge. The annual and monthly trends could well describe the effects of anthropogenic activities on the flow at different sections. In general, the method is feasible to provide support pertaining to water management or eco-hydrological researches and could be easily extended to other similar places.
\end{abstract}

\section{Introduction}

In most arid and semiarid regions, river laterally recharges the riparian groundwater to sustain the terrestrial ecosystem along the natural channel and impact interactions between food, water, and energy in oasis [1-3]. Discharge data especially in arid and semiarid regions is quite important for water resource management and related scientific researches. However, insufficient data or the lack of information renders many tasks difficult [4]. A recent study has focused on ecohydrological effects of stream-aquifer water interaction in an inland river basin [5]. But due to lacking of discharge data, the research of long-term riparian ecohydrological effects is trapped. Many hydrologists have tried to address this issue using simple regression methods to demonstrate the value of providing a rough control on water flow in regions characterized by scarce data [6-8]. A nonlinear regression model of a hydrological system could obtain rational outcome without requiring additional information, such as evaporation or soil moisture [9]. More complicated statistical models built on seasonal-based grouped catchments bring more robust results [10-12]. Physical models of gauged and ungauged basins have been studied more thoroughly and include regionalizing model parameters, constraining hydrologic simulations by regionalized signatures [13-16] and assigning parameters from similar hydrological catchments $[17,18]$. These models are principally hampered by unsound calibration [19]. Although the transferability of parameters estimation methods from small subcatchments to a large area performs well in some case, the common contention of comparing physical and functional similarities may be invalid for many catchments $[14,20]$. Diversity in climatic variability and geographical attributes causes different performances for each regionalization method in various regions 
[21]. To overcome this deficiency, more complicated models with adequate spatial and temporal information have been used, such as CLM, MIKE SHE, GSFLOW, and CATHY [22-25]. Although these process-based models can better describe the exchange of surface water and groundwater, the high computational cost makes it difficult to apply to large basins [26]. Long-term simulations by these models depend on spatiotemporally continuous forcing, which is however difficult to meet, especially in ungauged areas.

The Heihe River Basin (HRB), the second largest inland river basin in China, is located in a transitional zone straddling semiarid and arid areas. There is an obvious interaction between human activity, such as water use, and basin ecosystem [27], leading to substantial research focused on hydrological processes [28-32] and water resources management [33-35]. The discharge is an important indicator of the availability of water for the ecosystem in the middle and lower reaches of HRB [36]. However, there is only one hydrologic station (i.e., the Gaoya hydrologic station) between the inlet (i.e., the Yingluoxia hydrologic station) and the outlet (i.e., the Zhengyixia hydrologic station) located in the midstream [37] generating a typical discharge-ungauged problem for this river reach [38]. It is imperative to estimate the discharge at ungauged sections for the past decades to strengthen the water management. Previous studies have produced several useful methods and data; few of them however have explicitly addressed the issue of the long-term discharge estimation at different ungauged locations in the reach.

As part of a major initiative to provide a complete scientifically based planning for sustainable water management in arid and semiarid ecosystems, a monthly discharge estimation procedure based on spatiotemporally discontinuous data, was proposed using diversion for irrigation water, water allocation planning, water budget of the inland river, and statistical relations of discharge at different locations. In this work, monthly discharge from 1979 to 2014 at four unmonitored river sections and that from 1991 to 2007 at one gauged section were estimated using this procedure. The HRB is taken as a case study to propose an appropriate procedure for discharge estimation in ungauged rivers and provide data for long-term discharge to support water resource management and further ecohydrological studies in HRB.

\section{Methodology}

For ungauged river sections in arid and semiarid basins, we established a procedure of monthly discharge estimation with spatiotemporally discontinuous data information including those on human activities. Under natural circumstance, the main equilibrium of the river water volume is determined by the inflow, outflow, precipitation, evaporation, river leakage, and recharge from groundwater. For a river flowing in an arid area, the inflow from the upper mainstream principally dictates the total river water quantity of the middle and lower basin reaches. Thus, knowing the accurate inflow will provide the upper limit of water flow. Because of complicated hydrogeological distribution in arid and semiarid zones, factors such as river leakage and recharge from groundwater become more important than those in humid regions [39]. The lack of reliable data at the river scale produces uncertainties in determining different components. Because of limited data on precipitation and evaporation, these are given as a fixed seasonal change. Moreover, a large number of the population relies on the HRB for their subsistence so the effect of human disturbance on streamflow cannot be ignored [40]. Different demands for water diversion should be considered for irrigation and nonirrigation periods. The water diversion activity is intensive on some river reaches whereas there is no obvious human influence on others. Intense human activity in oasis segments occurring in the middle reach can severely restrict sustainable eco-development in the lower reaches of the HRB [41]. To ensure a sufficient water delivery to downstream ecosystems, the government instances would usually take action to limit the use of water [42]. This operation can affect the natural discharge along the river. However, it is difficult to obtain the detailed water allocation data. Hence, we need to incorporate a suitable parameter into the water balance equation to reflect the effect of governmental management on the quantity of river drainage. A water balance framework for river flowing in arid and semiarid regions is given in Figure 1. Because the monthly discharge estimation procedure is based on spatiotemporally discontinuous data, any term of the water balance could be calculated from any possible data. For example, if there are surveyed data or known statistical relations, they can be directly used for calculation. Otherwise, the indirect relations between any terms of the water balance at different or same locations should be established on estimated data at previous step. Main equation is shown below:

$$
\begin{aligned}
Q_{\text {out,month }}= & P_{\text {month }}+Q_{\text {in,month }}-Q_{\text {use,month }}-E_{\text {in-out }} \\
& -Q_{\text {in,month }} \times D_{\text {in-out }} \times \delta_{\text {in-out }}+\Delta S_{\text {in-out }} .
\end{aligned}
$$

$Q_{\text {out,month }}$ means the monthly discharge at the section of outlet along the river reach; $P_{\text {month }}$ denotes recharge from precipitation; $Q_{\mathrm{in}, \mathrm{month}}$ is the discharge at the section of inlet along the river reach; $Q_{\text {use,month }}$ is the water extracted from river for irrigation by human; $E_{\text {in-out }}$ is the evaporation from the upper section to the lower section; $D_{\text {in-out }}$ means the distance between the two locations; $\delta_{\text {in-out }}$ is the water leakage rates from riverbed or recharge rate from groundwater per distance, which is calculated by statistical formulas; $\Delta S_{\text {in-out }}$ is the change of river water storage in each month. Water balance law is suitable for all segments of study area although $Q_{\text {use,month }}$ and $\delta_{\text {in-out }}$ could be ignored in some river reaches without significant human activities and exchange of surface and subsurface water. Discharge estimation in this paper is primarily based on the equation and other statistical relations of discharge between different river sections. It means some terms, such as $\delta_{\text {in-out }}$, would be estimated by statistical relations investigated from previous studies by others. Moreover, if the direct relation of discharge between two sites exists, it would also be used for calculation. Then the results calculated, respectively, from water balance equations and statistical relations should be averaged to be a robust result. 


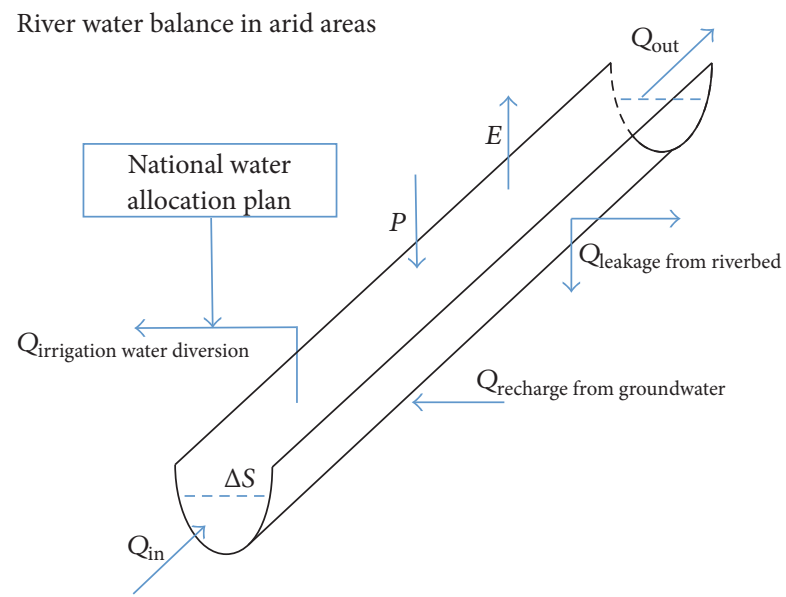

FIgURE 1: A water balance framework for a river flowing in arid and semiarid regions.

\section{Numerical Simulation}

3.1. Study Area. The HRB covers a total area of $143,000 \mathrm{~km}^{2}$ and is the second largest inland river basin in China, located at $98^{\circ} \mathrm{E}-102^{\circ} \mathrm{E}$ and $37^{\circ} \mathrm{N}-42^{\circ} \mathrm{N}$. Water flowing from the headwater to downstream controls the landscape. Glaciers and permafrost are present in the high-mountain areas while forests and alpine meadows cover the middle-mountain regions. A desert-oasis-river landscape occurs in the middle and lower basin reaches, with well-developed agriculture in the midstream and a riparian ecosystem distributed downstream along the river. In the upstream basin, the mean annual precipitation is approximately $300-700 \mathrm{~mm}$ with distinct vertical zonal divisions. The upper reaches of the HRB contain nearly the entire water resource of the whole basin [43]. In the middle reaches, the elevation decreases from $2000 \mathrm{~m}$ to $1000 \mathrm{~m}$ and the precipitation correspondingly decreases from south to north from $200 \mathrm{~mm}$ to $100 \mathrm{~mm}$ [44]. The lower reaches having an average altitude of $1000 \mathrm{~m}$ constitute an arid region with a mean annual precipitation of $42 \mathrm{~mm}$ according to statistical data gathered from meteorological stations and simulations from regional climate models [45]. Conflicts between districts related to specific types of water demands have long prevailed in the region. The national water allocation plan effectively solved the conflicts [46] by closing all channels so that enough water can arrive at the lower reaches.

In this work, four ungauged river cross-sections were selected, namely, the Caotanzhuang site, the S213 Bridge, the G312 Bridge, and the Tielu Bridge. The Gaoya station and Zhengyixia station, both of which are the lower sites compared to Tielu Bridge in the middle reach, were selected to validate the procedure. All are located in the midstream area and shown in Figure 2. The middle reach experiences different hydrogeological conditions. From the Yingluoxia Gorge to the location near the G312 Bridge, the river level is higher than groundwater level so that groundwater recharge occurs through leakage of the riverbed [35]. Along this river reach, there is intensive human activity leading to water diversion from the Yingluoxia Gorge to the Caotanzhuang, whereas there is little water diversion in other parts. The river is again affected by water diversion from the G312 Bridge to the Tielu Bridge. The groundwater recharges the river from the G312 Bridge to the outlet (Zhengyixia Gorge) in the midstream $[35,47]$. Then diversion for irrigation water reappears in some river reaches.

3.2. Data. Some important data, such as measured discharge at Yingluoxia, Gaoya, and Zhengyixia, were collected from the Hydrological Bureau of the Gansu Province, the Heihe River Bureau [48, 49]. Other data, such as estimated evaporation and monthly water diversion from river, were extracted mainly from the literature $[29,50]$. Note that replenishment by precipitation is sometimes ignored because of the scant rainfall in the entire middle reaches [45]. Data would be introduced in detail in the following.

\subsection{Estimation of Monthly Discharge at Ungauged River} Sections. Downstream calculations, shown in Figure 3, were used to estimate the monthly discharge. The mainstream was divided into four parts. Part 1 runs from the Yingluoxia Gorge to the Caotanzhuang section $(\sim 10 \mathrm{~km})$, Part 2 spans the Caotanzhuang site to the S213 Bridge $(\sim 12 \mathrm{~km})$, Part 3 starts from the S213 Bridge and ends at the G312 Bridge $(\sim 12 \mathrm{~km})$, and Part 4 goes from the G312 Bridge to the Tielu Bridge $(\sim 3 \mathrm{~km})$. We initially used the monitored 1979 to 2010 monthly discharge, the 2011 to 2014 simulated monthly discharge, and the observed annual discharge [48, 49] at the Yingluoxia Gorge to generate a prolonged and precise series of monthly discharges. We then estimated monthly discharges at the Caotanzhuang, the S213 Bridge, the G312 Bridge, and the Tielu Bridge based on statistical and water balance methods that included water diversion for irrigation, river leakage, evaporation, and the national water allocation plan.

As described above, there is intense human activity related to water diversion from Yingluoxia to Caotanzhuang while there is nearly no water diversion in other parts of the river reach from Yingluoxia to Tielu Bridge. Accurate discharge estimation from the Yingluoxia Gorge to the Caotanzhuang hydrojunction will dictate the reliability of all discharge estimates downstream due to the water diversion caused by human activity. The water diversion related to irrigation and the national water allocation plan will also substantially modify the total discharge. Therefore, we adopted a statistical regression method and a water balance equation to calculate the discharge and then averaged the two results to reduce the uncertainty related to the methodologies. In the statistical regression method, we applied different calculations during the irrigation periods and the nonirrigation periods of January, February, and December. For the nonirrigation periods, a linear regression, shown as (2), was defined by the measured monthly discharge from the Yingluoxia and Caotanzhuang sites during the closed channels periods of 2011 and 2012 [51]. The unit is $\mathrm{m}^{3} / \mathrm{s}$. The coefficient of determination is larger than 0.90 and it could be applied in January, February, and December. 


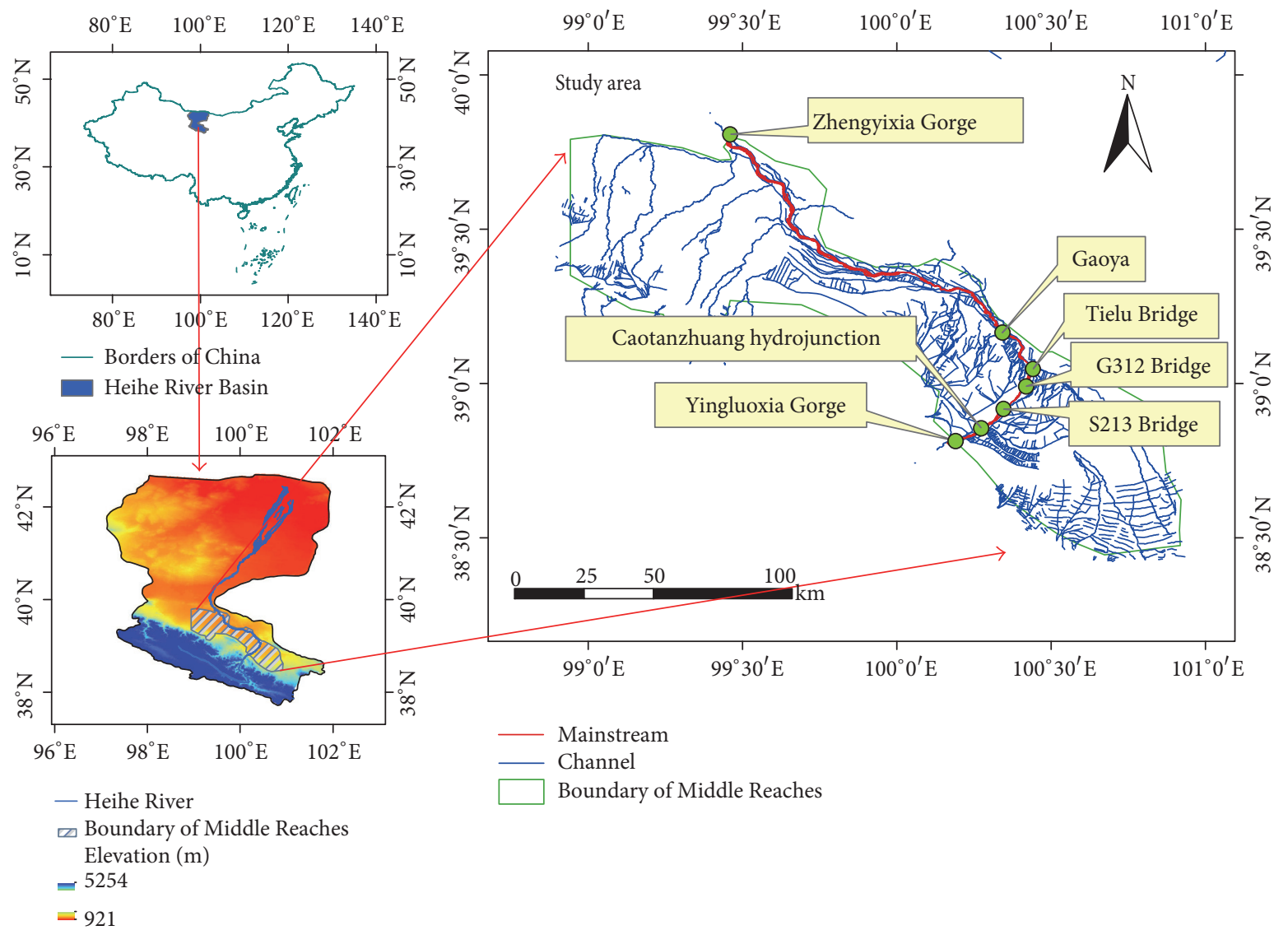

FIGURE 2: Locations of main river sections in the middle reach of Heihe River.

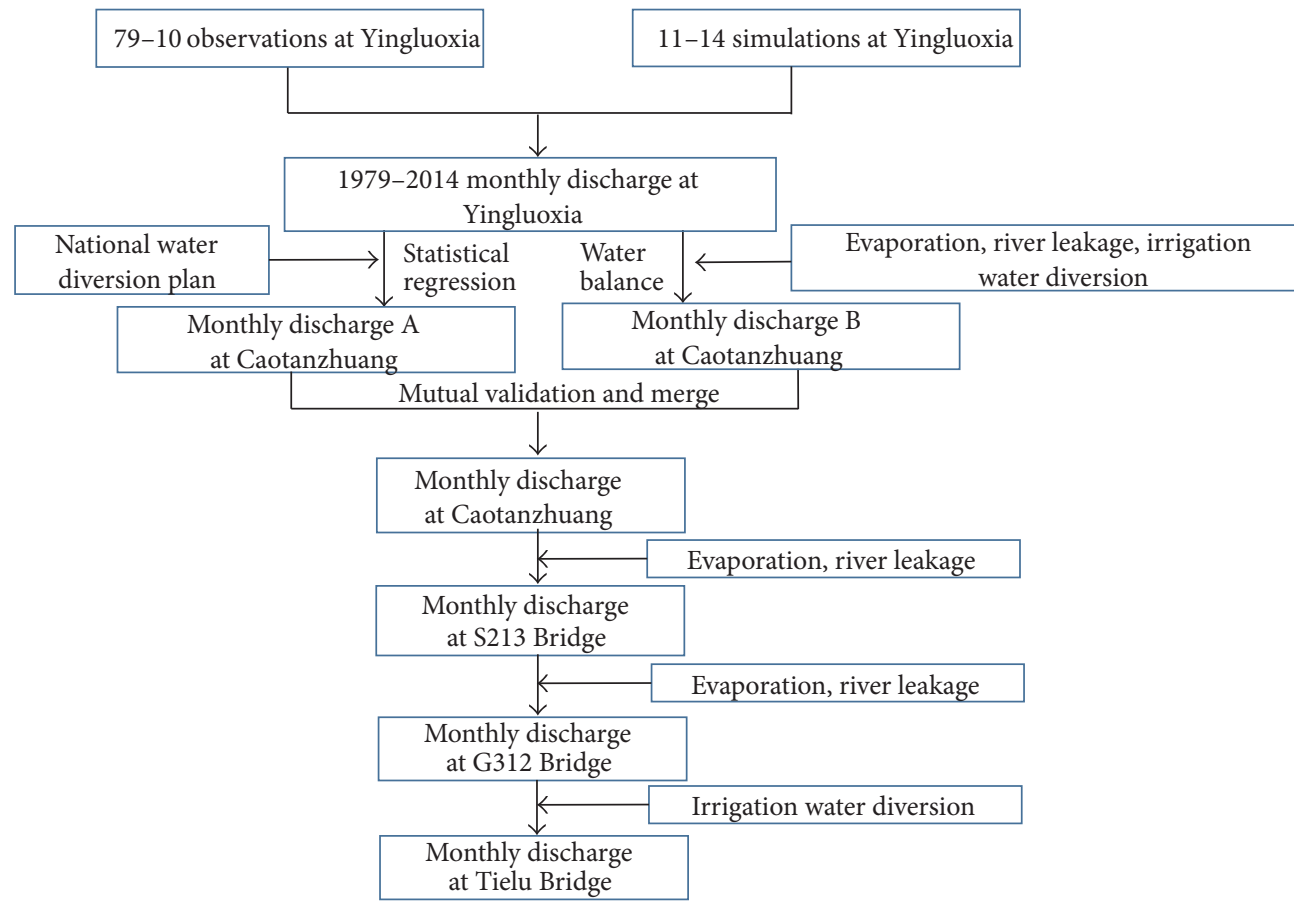

FIGURE 3: Flowchart of discharge estimation at ungauged river sections. 
Another empirical equation, shown as (3), was found by the measured discharge from the Yingluoxia and Caotanzhuang sites during 1998 to 2001 [29] for the irrigation period. The unit is $10^{8} \mathrm{~m}^{3} /$ month. The coefficient of determination is about 0.90 and it could be used during other months. Due to lacking of monitoring, these equations from literatures could be deemed to be relatively believable in this paper.

$$
\begin{aligned}
& Q_{\text {ctz,month }}=0.9566 \times Q_{\text {ylx,month }}-2.4473 \\
& Q_{\text {ctz,month }}=0.1279 \times Q_{\text {ylx,month }}^{2}+0.0953 \times Q_{\text {ylx,month }} .
\end{aligned}
$$

$Q_{\text {ctz,month }}$ denotes the monthly discharge at the Yingluoxia section; $Q_{\text {ctz,month }}$ means the monthly discharge at the Caotanzhuang site. Because the statistical computation was performed for the transitional period tentatively implementing the national water allocation plan, it is necessary to tune the results. To satisfy this constraint, we recalculated the discharge at the Zhengyixia site when it reached $15.8 \times 10^{8} \mathrm{~m}^{3}$ at the Yingluoxia location. We then calculated the ratios of the computed annual discharge of the 1979 to 1997 and 2002 to 2014 periods to the average annual discharge from 1998 to 2001 from the Zhengyixia site. The specific equations are shown in (4). Monthly discharge before 1998 was then corrected by the obtained ratios. The data after 2001 period were corrected using these determined ratios only if current monthly discharge given at Yingluoxia location grew more than $5 \%$ relative to the sum of the multiyear averaged monthly discharge and the standard deviation both of which were calculated by data from 1990 to 1999 . The value of $5 \%$ is an assumed threshold by experience.

$$
\begin{aligned}
& Q_{\text {ctz_adjust,month }}=\left[\frac{\left(\theta_{\text {year }} \times 12\right)}{9}\right] \times Q_{\text {ctz,month }}, \\
& Q_{\text {ctz_adjust,month }}=\left[\frac{\left(\theta_{\text {year }} \times 12\right)}{N_{\text {year }}}\right] \times Q_{\text {ctz,month }} .
\end{aligned}
$$

$Q_{\text {ctz_adjust,month }}$ indicates the revised monthly discharge at the Caotanzhuan location; $\theta_{\text {year }}$ stands for the correction ratio; $N_{\text {year }}$ signifies the number of months when the current monthly discharge at the Yingluoxia is 5\% higher than the sum of the monthly mean and the standard deviation. To ensure the reliability of the results, we need check the computations in a different way. To get a more credible discharge at the Caotanzhuang site, we substituted the river seepage equations, shown as (5) and (6) with the coefficient of determination of 0.89 and 0.98 , respectively, and provided by literatures $[28,29]$ and the 1990 to 2007 monthly extracted water data [50] of five irrigated areas (Daman, Yingke, Xigan, Gansuo, and Shangsan) into the river water balance shown as (7). The final river leakage is obtained by averaging the calculated results by two river leakage descriptions.

$$
\begin{aligned}
\delta_{\text {ylx }-\mathrm{G} 312} & =11.8488 \times Q_{\mathrm{ylx}, \text { month }}^{-0.6867}, \\
\delta_{\mathrm{ylx}-\mathrm{ctz}} & =0.01266+\frac{0.019}{Q_{\mathrm{ylx}, \text { month }}},
\end{aligned}
$$

$$
\begin{aligned}
Q_{\text {ctz,month }}= & P_{\text {month }}+Q_{\text {ylx } \text { month }}-Q_{\text {use,month }}-E_{\text {ylx-ctz }} \\
& -Q_{\text {ylx,month }} \times D_{\text {ylx-ctz }} \times \delta .
\end{aligned}
$$

The left variables of (5) and (6) are the leakage rates per distance. The units of $\delta_{\mathrm{ylx}-\mathrm{G} 312}$ and $\delta_{\mathrm{ylx} \text {-ctz }}$ are $\left(\% \times \mathrm{km}^{-1}\right)$ and $\left(\mathrm{km}^{-1}\right)$, respectively. Equation (7) is the river water balance model in study area. The term $\Delta S_{\text {up-down }}$ in (1) is ignored because it is small in river reach with a very short distance for one month. $E_{\text {ylx-ctz }}$ is set to a constant extracted from the literature. $Q_{\text {use,month }}$ denotes the irrigation water diversion. Using these equations, we obtain the monthly discharge from 1990 to 2007 at the Caotanzhuang site based on the water balance method. Estimated discharges from 1990 to 2007 based on statistical regression and the water balance method applied to the Caotanzhuang site are shown in Figure 4. The estimated results from the statistical regression and water balance methods are consistent. The calculated Nash-Sutcliffe coefficient (NSE) [52] is 0.86 , the correlation coefficient is 0.95, and the Root Mean Square Error (RMSE) is $11.38 \mathrm{~m}^{3} / \mathrm{s}$, which shows the results provided by the statistical regression, and water balance methods are reasonable and comparable. The regression equations were applied using the monthly discharge from 1990 to 1999 and from 2000 to 2007 to extend the results to the range from 1979 to 2014 . As shown in Figures 4(b) and 4(c), the linear regression equations are listed with coefficient of determination of 0.93 and 0.90 , respectively, for the 1990-1999 and 2000-2007 periods. Both regression equations passed the significance test. Estimated monthly discharge for the 1979-1989 and 2008-2014 periods by statistical modeling was applied to complement the discharge obtained by the water balance method and linear regression equations. The two calculated results were then averaged to get a more reliable data. Once the monthly discharge at the Caotanzhuang site was determined, the discharge at the S213 Bridge and G312 Bridge river sections was calculated in the similar way. The main equations used for these river reaches are listed as follows:

$$
\begin{aligned}
\delta_{\text {ctz-S213 }}= & 0.008+\frac{0.592}{Q_{\text {ctz,month }}}, \\
\delta_{\mathrm{S} 213-\mathrm{G} 312}= & 0.036+\frac{0.48}{Q_{\mathrm{S} 213, \text { month }}}, \\
Q_{\text {out,month }}= & P_{\text {month }}+Q_{\text {in,month }}-E_{\text {in-out }}-Q_{\text {in,month }} \\
& \times D_{\text {in-out }} \times \delta .
\end{aligned}
$$

The in and out mark the location of the inlet and outlet of the river reach from Caotanzhuang to S213 Bridge or that from S213 Bridge to G312 Bridge. Because there is hardly water diversion from the Caotanzhuang site to the G312 Bridge,

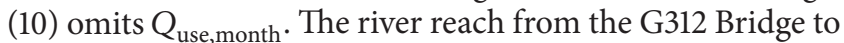
the Zhengyixia location is a water gaining segment, but there is no detailed information on the segment from the G312 Bridge to the Tielu Bridge. The distance between the G312 Bridge and the Tielu Bridge is only $3 \mathrm{~km}$; we ignored both the river leakage and the recharge from groundwater and integrated the water extracted for Wujiang irrigation district. 


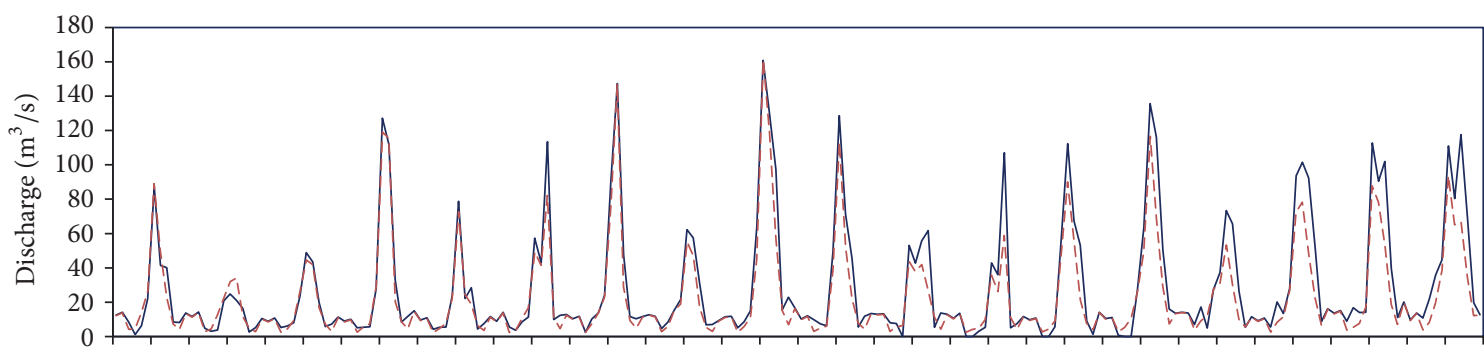

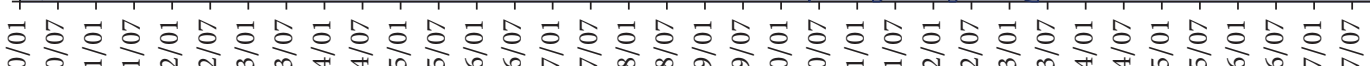

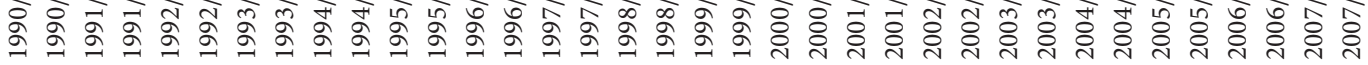

- Water balance method

--- Statistical regression method

(a)

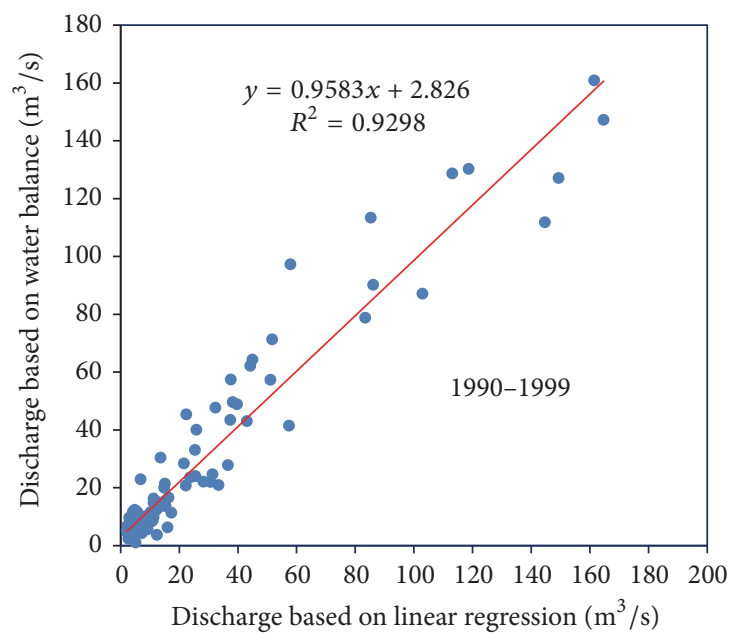

(b)

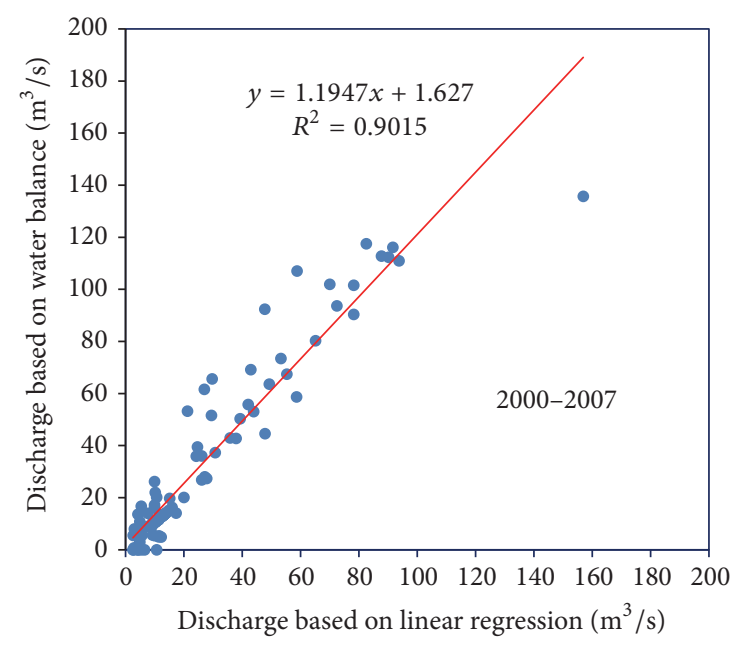

(c)

FiguRE 4: 1990-2007 estimated discharge at the Caotanzhuang (a) and correlations between the results by regression and water balance method, respectively (b-c).

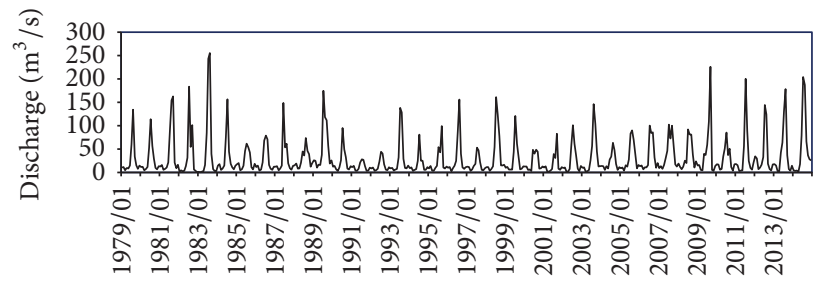

(a)

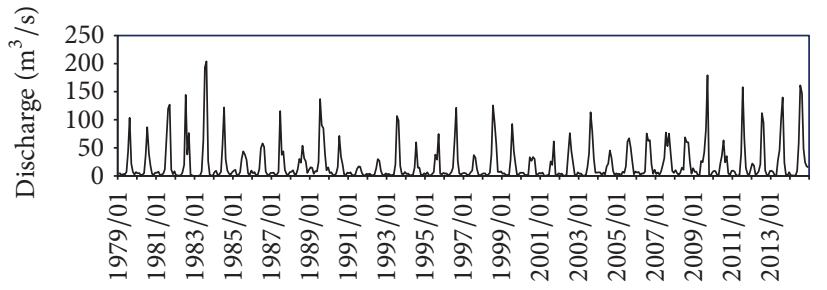

(c)

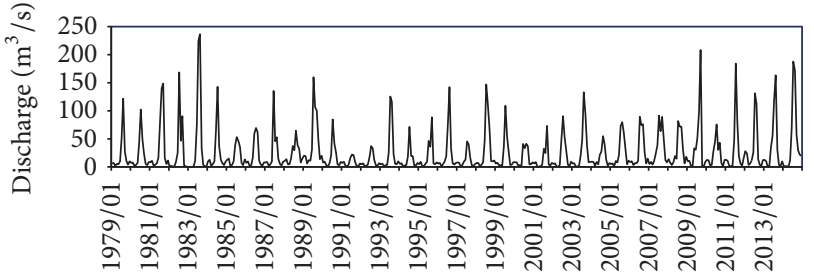

(b)

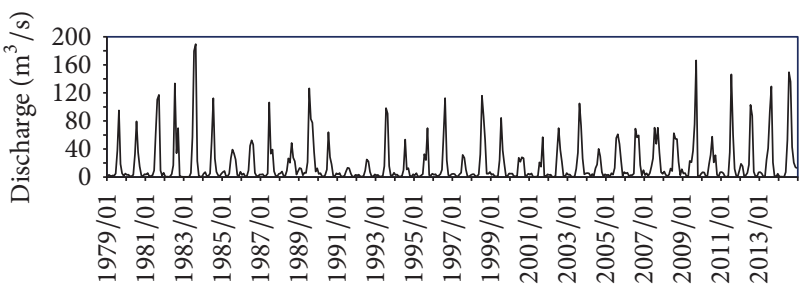

(d)

Figure 5: 1979-2014 estimated discharge at the Caotanzhuang (a), the S213 Bridge (b), the G312 Bridge, (c) and the Tielu Bridge (d). 


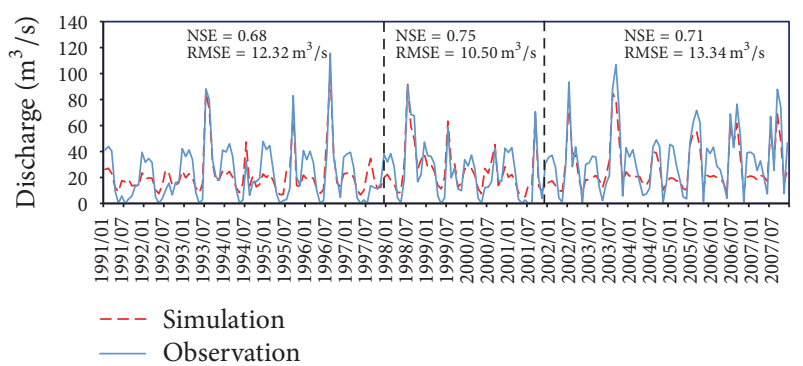

FigURE 6: 1991-2007 simulated and observed monthly discharge at the Zhengyixia.

The estimated monthly discharge at four ungauged sections is shown in Figure 5.

3.4. Validation of the Procedure and the Estimated Discharge. The proposed procedure and the estimated discharge were validated by two steps. Firstly, the observed monthly data at Zhengyixia station, which belongs to the segment lower than that from Yingluoxia to Tielu Bridge, was used to validate the procedure. Then the trend analysis of estimated annual and monthly discharge was implemented to indirectly check the facticity of the estimated data.

The proposed procedure was used to estimate the monthly discharge at the outlet (Zhengyixia station) of the middle reach based on the limited data of the segment from Gaoya to Zhengyixia. Difference from the river reaches mentioned in Section 3.3 is that the groundwater chiefly recharges the river in this part. Recharge from groundwater was estimated based on the literature [29]. The total water extracted from river was computed based on shared data [50]. Then the input data from 1991 to 2000, such as precipitation, evaporation, observed discharge at Gaoya station, recharge from groundwater, and water diversion for irrigation, were collected and processed for water balance computing. Similar to the method used for the segment from Yingluoxia to Caotanzhuang, a linear regression relation was built on the observed data from 1998 to 2001 at Gaoya and Zhengyixia stations. The average of the data calculated by the two ways was regarded as the final result. The final estimated data from 1991 to 1997 and from 2002 to 2007 were compared with the observation at Zhengyixia station to validate the proposed procedure. The simulated result is shown in Figure 6. The results of NSE in two periods for validation are, respectively, about 0.70 , which is satisfactory. Although the simulation does not match well with the observation during some seasons, the main change of monthly discharge could be captured. The gap between simulation and observation may be mainly attributed to three aspects. The first is the uncertainty of data related to human activities. The data just describe the total water extracted from river but ignore the distribution at cultivated land so that the lag of backing to river by overland flow may be difficult to be considered. The second aspect is the recharge from groundwater. Because the distance from Gaoya to Zhengyixia is about four times as long as that from Yingluoxia to Tielu Bridge, there may be more uncertainties of calculating recharge rate along the

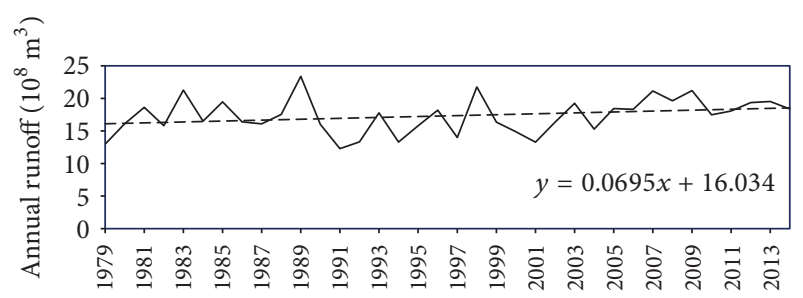

(a)

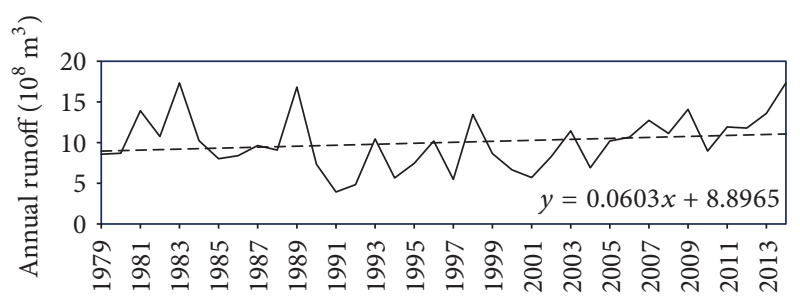

(b)

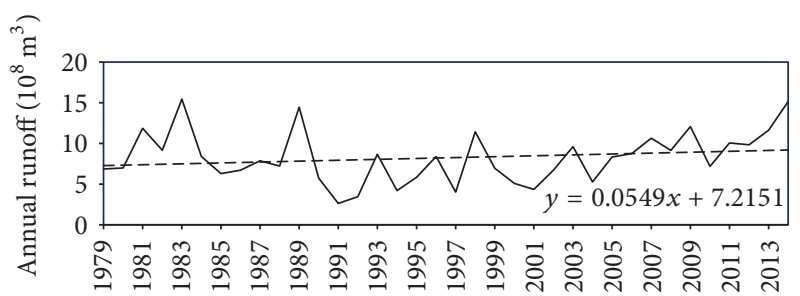

(c)

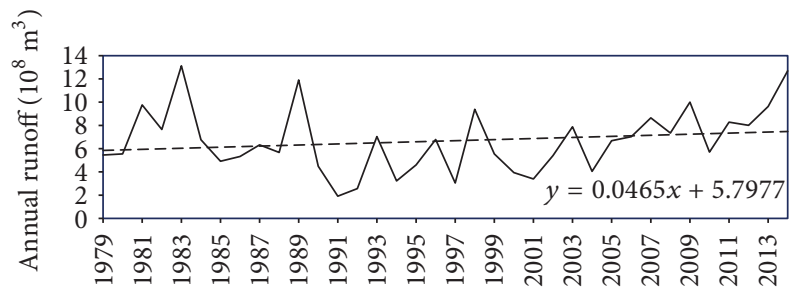

(d)

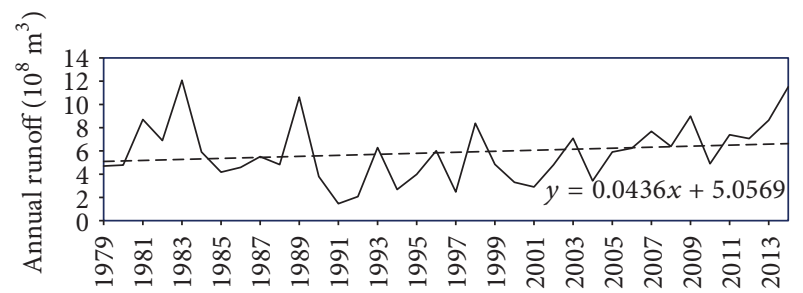

(e)

FIGURE 7: 1979-2014 estimated annual runoff trend based on regression analyses at the Yingluoxia (a), Caotanzhuang (b), the S213 Bridge (c), the G312 Bridge, (d) and the Tielu Bridge (e).

river. The third aspect is the regression relation based on linear assumption, which is however not in accord with the true world. In general, according to this validation, for the ungauged inland river in an arid and semiarid area, the design idea of the discharge estimation is reliable.

Based on regression analysis, presented in Figure 7, an increasing trend of discharge from 1979 to 2014 is observed. The amount of water at the Yingluoxia Gorge controls the upper limit of the downstream sectional flow. The annual 


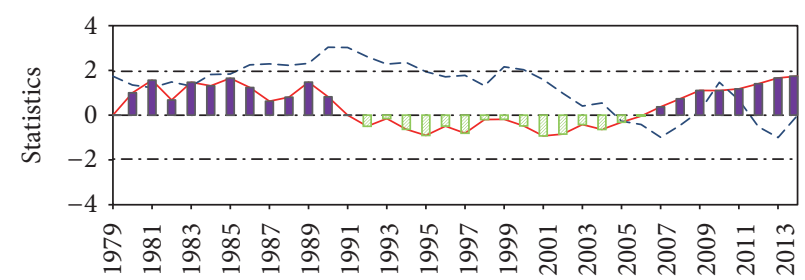

(a)

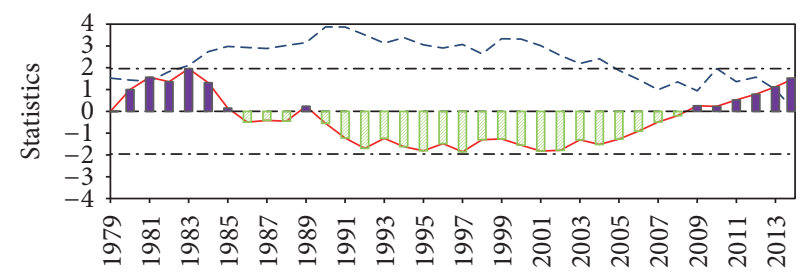

(c)

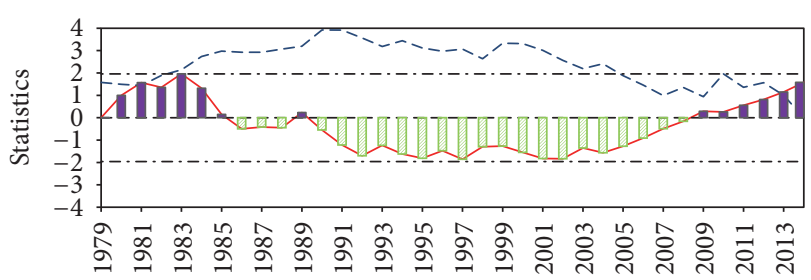

(b)

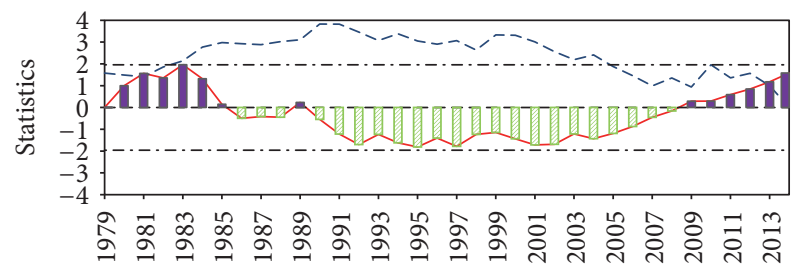

(d)

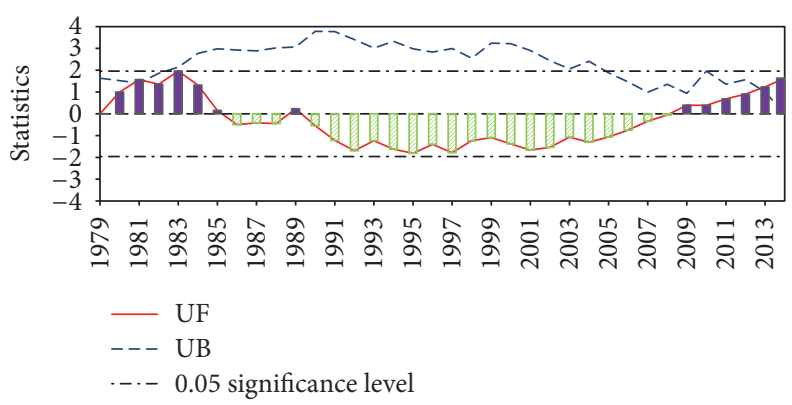

(e)

Figure 8: 1979-2014 estimated change in annual runoff based on the sequential Mann-Kendall test at the Yingluoxia (a), the Caotanzhuang (b), the S213 Bridge (c), the G312 Bridge (d), and the Tielu Bridge (e).

rates of increase at the Yingluoxia, the Caotanzhuang hydrojunction, the S213 Bridge, the G312 Bridge, and the Tielu Bridge are $0.0695 \times 10^{8} \mathrm{~m}^{3} / \mathrm{a}, 0.0603 \times 10^{8} \mathrm{~m}^{3} / \mathrm{a}, 0.0549 \times$ $10^{8} \mathrm{~m}^{3} / \mathrm{a}, 0.0465 \times 10^{8} \mathrm{~m}^{3} / \mathrm{a}$, and $0.0436 \times 10^{8} \mathrm{~m}^{3} / \mathrm{a}$, respectively. Declining rates are in turn observed especially in the segments from the Yingluoxia to Caotanzhuang locations and from the S213 Bridge to the G312 Bridge. This may reflect an important water diversion and river leakage. This result is in agreement with the mainstream exchange flux variation determined by Tian et al. (2015) [35]. The result of the sequential Mann-Kendall test described in the literature [53] is shown in Figure 8. Both UF and UB in the figure are sequential statistics. If the value of UF is greater than 0 , there is a rising trend and vice versa. If it is greater than 1.96 or less than -1.96 , the change trend is statistically significant. The intersection of UF and UB denotes a change point over the time series. From the figure, it indicates a rising trend of annual runoff at the Yingluoxia location from 1979 to 1990, a downward trend from 1991 to 2006 followed by an increasing trend from 2007 to 2014. Annual runoff at other sections consistently displays a downward trend from 1985 to 2007 followed by an increase after 2007. The difference in runoff among ungauged sections is not apparent. A noticeable variation occurs in 2006 at the Yingluoxia site while those at other sites lag behind. This may be explained by climatic factors controlling the discharge at the Yingluoxia location whereas the discharge at midstream is affected by human activity and geological features. We further analyzed the variation in multiyear averaged monthly discharge by dividing the whole period into three periods. The river was less affected by human activity during the period of 1979-1989. Intensive effect of human activity existed in the period of 1990-2000. The national water allocation plan was carried out during the 2001-2014 period. Figure 9 shows the discharge at all sections exhibiting significant seasonal changes. The discharge at the Yingluoxia site varies slightly for the three periods. There is a peak discharge of $140 \mathrm{~m}^{3} / \mathrm{s}$ consistently occurring in July. During the high flow periods of June, July, August, and September, the ungauged sections discharge varies between 60 and $110 \mathrm{~m}^{3} / \mathrm{s}$ in the first period, declines from 40 to $80 \mathrm{~m}^{3} / \mathrm{s}$ in the second, and rises to a higher range in the last period. At Gaoya station, the monthly discharge is larger than that at Yingluoxia station in winter and spring. This is perhaps due to the fact that the groundwater recharges the streamflow around that place. Since 2000, the national water allocation plan was gradually implemented to generate an amount of ecologically satisfactory water level in the lower reaches of the HRB. On the whole, although the proposed monthly 

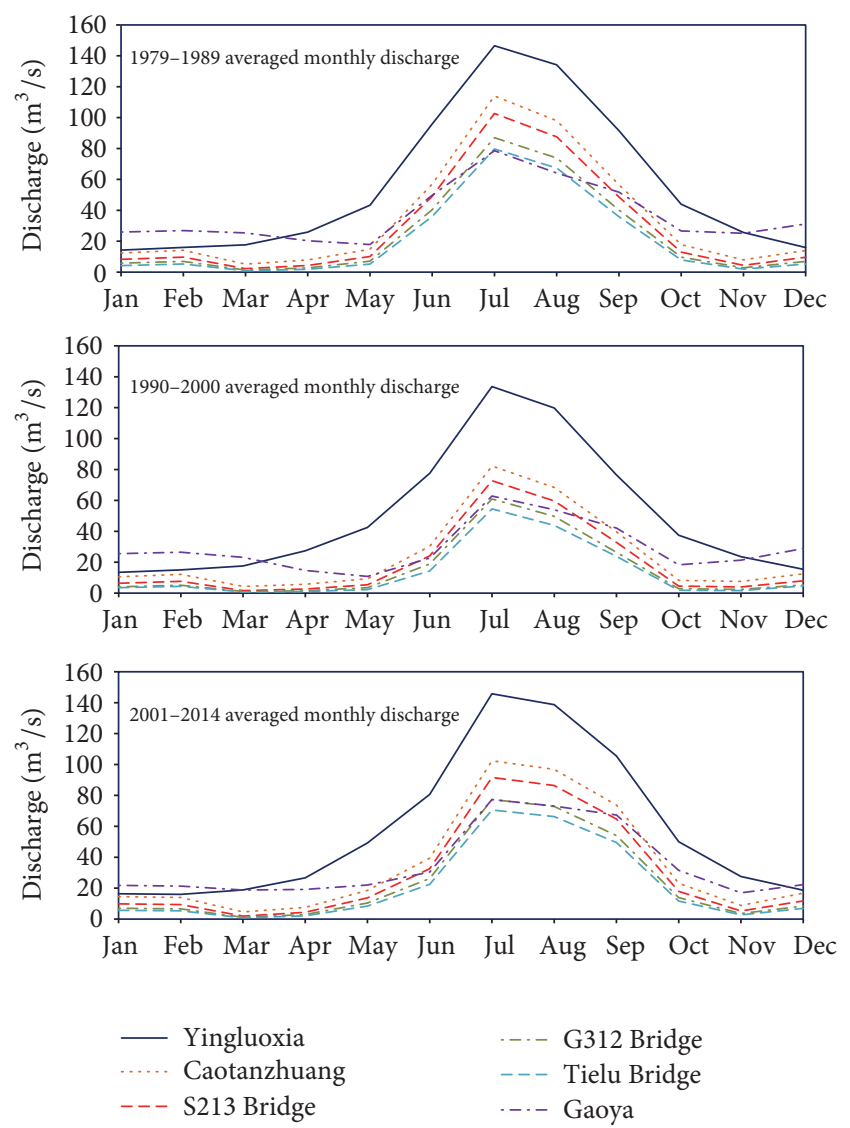

FIGURE 9: Multiyear averaged monthly discharge trends in three different periods.

discharge estimation method could not fairly accurately calculate the discharge, the estimated streamflow at ungauged river could be appropriate and satisfactory.

\section{Conclusions and Discussion}

In the arid and semiarid areas, streamflow plays an important role in riparian water-energy-food nexus under frequent human activities. However, the unsurveyed discharge data may make related works trapped. It is important to take full advantage of fragmentary data to estimate a long-term discharge in an ungauged river reach. In this work, a procedure of monthly discharge estimation for an ungauged inland river was proposed based on spatiotemporally discontinuous data information including those on human activities. Monthly discharge from 1979 to 2014 at four unmonitored river sections (the Caotanzhuang, the S213 Bridge, the G312 Bridge, and the Tielu Bridge) and that from 1991 to 2007 at one gauged section (Zhengyixia) were estimated using this procedure. The observed data at Zhengyixia was used to validate the procedure. The Nash-Sutcliffe coefficient and Root Mean Square Error are, respectively, about 0.70 and $13.00 \mathrm{~m}^{3} / \mathrm{s}$, which shows its potential in estimating discharge for an ungauged area. The trend analysis for discharge at four ungauged river sections was conducted to indirectly check the facticity of the estimated data. From annual trends, the calculated data probably reflects surface and subsurface water interaction. The monthly trends show that the national water allocation plan improved the ecological water supply to the lower reaches of the Heihe River Basin. Annual and monthly trend could well describe the effects of anthropogenic activities on the flow at different sections. In summary, the proposed discharge estimation procedure for ungauged rivers is reliable and this work also provided the long-term discharge data for different ungauged river sections to support water resource management and scientific researches of riparian waterenergy-food nexus in HRB. But even more importantly, this procedure could be easily extended to other similar ungauged inland rivers.

Most of available data were employed to estimate the discharge in the study area. However, those data did not include factors such as Land Use/Cover Change [54] and the economic policy [55]. Moreover, a long-term continuous flow monitoring at ungauged sections [36] should be set up to calibrate and validate our method or other hydrological models. A recent airborne thermal infrared remote sensing study indicates the possibility of quantifying the groundwater discharge of a river [56], which may be useful for discharge estimation.

\section{Additional Points}

The estimated data can be obtained upon request from the authors and would be permanently archived at the Cold and Arid Regions Science Data Center at Lanzhou, http://westdc .westgis.ac.cn/data/9fb70559-fe79-4f99-bal1-3f02cdd184b0 [57].

\section{Competing Interests}

The authors declare that they have no competing interests.

\section{Acknowledgments}

This study was supported by the National Natural Science Foundation of China (Grants 41575096 and 91125016) and by the Key Research Program of Frontier Sciences, CAS (Grants QYZDY-SSW-DQC012).

\section{References}

[1] B. R. Scanlon, R. W. Healy, and P. G. Cook, "Choosing appropriate techniques for quantifying groundwater recharge," Hydrogeology Journal, vol. 10, no. 1, pp. 18-39, 2002.

[2] Y. Chen, Y. Chen, C. Xu et al., "Effects of ecological water conveyance on groundwater dynamics and riparian vegetation in the lower reaches of Tarim River, China," Hydrological Processes, vol. 24, no. 2, pp. 170-177, 2010.

[3] Y. Zeng, Z. Xie, Y. Yu et al., "Effects of anthropogenic water regulation and groundwater lateral flow on land processes," Journal of Advances in Modeling Earth Systems, vol. 8, no. 3, pp. 1106-1131, 2016.

[4] J. Seibert and K. J. Beven, "Gauging the ungauged basin: how many discharge measurements are needed?" Hydrology and Earth System Sciences, vol. 13, no. 6, pp. 883-892, 2009. 
[5] Y. Zeng, Z. Xie, Y. Yu et al., "Ecohydrological effects of streamaquifer water interaction: a case study of the Heihe River basin, northwestern China," Hydrology and Earth System Sciences, vol. 20, no. 6, pp. 2333-2352, 2016.

[6] M. Sivapalan, K. Takeuchi, S. W. Franks et al., "IAHS decade on Predictions in Ungauged Basins (PUB), 2003-2012: shaping an exciting future for the hydrological sciences," Hydrological Sciences Journal, vol. 48, no. 6, pp. 857-880, 2003.

[7] D. Mazvimavi, A. M. J. Meijerink, H. H. G. Savenije, and A. Stein, "Prediction of flow characteristics using multiple regression and neural networks: a case study in Zimbabwe," Physics and Chemistry of the Earth, vol. 30, no. 11-16, pp. 639647, 2005.

[8] L. Cheng, M. Yaeger, A. Viglione, E. Coopersmith, S. Ye, and M. Sivapalan, "Exploring the physical controls of regional patterns of flow duration curve-part 1: insights from statistical analyses," Hydrology and Earth System Sciences, vol. 16, no. 11, pp. 4435-4446, 2012.

[9] J. Song, J. Xia, L. Zhang, Z.-H. Wang, H. Wan, and D. She, "Streamflow prediction in ungauged basins by regressive regionalization: a case study in Huai River Basin, China," Hydrology Research, vol. 47, no. 5, pp. 1053-1068, 2016.

[10] C. Soulsby, D. Tetzlaff, and M. Hrachowitz, "Are transit times useful process-based tools for flow prediction and classification in ungauged basins in montane regions?" Hydrological Processes, vol. 24, no. 12, pp. 1685-1696, 2010.

[11] G. Laaha and G. Blöschl, "A comparison of low flow regionalisation methods-catchment grouping," Journal of Hydrology, vol. 323, no. 1-4, pp. 193-214, 2006.

[12] A. L. Mather and R. L. Johnson, "Event-based prediction of stream turbidity using a combined cluster analysis and classification tree approach," Journal of Hydrology, vol. 530, pp. 751-761, 2015.

[13] Z. Xie, F. Yuan, Q. Duan, J. Zheng, M. Liang, and F. Chen, "Regional parameter estimation of the VIC land surface model: methodology and application to river basins in China," Journal of Hydrometeorology, vol. 8, no. 3, pp. 447-468, 2007.

[14] L. Oudin, A. Kay, V. Andréassian, and C. Perrin, "Are seemingly physically similar catchments truly hydrologically similar?" Water Resources Research, vol. 46, no. 11, 2010.

[15] N. Bulygina, N. McIntyre, and H. Wheater, "Conditioning rainfall-runoff model parameters for ungauged catchments and land management impacts analysis," Hydrology and Earth System Sciences, vol. 13, no. 6, pp. 893-904, 2009.

[16] D. Biondi and D. L. De Luca, "Process-based design flood estimation in ungauged basins by conditioning model parameters on regional hydrological signatures," Natural Hazards, vol. 79, no. 2, pp. 1015-1038, 2015.

[17] S. D. Patil and M. Stieglitz, "Comparing spatial and temporal transferability of hydrological model parameters," Journal of Hydrology, vol. 525, pp. 409-417, 2015.

[18] T. Mittman, L. E. Band, T. Hwang, and M. L. Smith, "Distributed hydrologic modeling in the suburban landscape: assessing parameter transferability from gauged reference catchments," Journal of the American Water Resources Association, vol. 48, no. 3, pp. 546-557, 2012.

[19] K. Beven and J. Freer, "Equifinality, data assimilation, and uncertainty estimation in mechanistic modelling of complex environmental systems using the GLUE methodology," Journal of Hydrology, vol. 249, no. 1-4, pp. 11-29, 2001.

[20] C.-Y. Xu, "Testing the transferability of regression equations derived from small sub-catchments to a large area in central
Sweden," Hydrology and Earth System Sciences, vol. 7, no. 3, pp. 317-324, 2003.

[21] T. Razavi and P. Coulibaly, "Streamflow prediction in ungauged basins: review of regionalization methods," Journal of Hydrologic Engineering, vol. 18, no. 8, pp. 958-975, 2013.

[22] J. Zou, Z. Xie, Y. Yu, C. Zhan, and Q. Sun, "Climatic responses to anthropogenic groundwater exploitation: a case study of the Haihe River Basin, Northern China," Climate Dynamics, vol. 42, no. 7-8, pp. 2125-2145, 2014.

[23] J. Windolf, H. Thodsen, L. Troldborg et al., "A distributed modelling system for simulation of monthly runoff and nitrogen sources, loads and sinks for ungauged catchments in Denmark," Journal of Environmental Monitoring, vol. 13, no. 9, pp. 26452658, 2011.

[24] S. L. Markstrom, R. G. Niswonger, R. S. Regan, D. E. Prudic, and P. M. Barlow, "GSFLOW-coupled ground-water and surface-water FLOW model based on the integration of the Precipitation-Runoff Modeling System (PRMS) and the Modular Ground-Water Flow Model (MODFLOW-2005)," US Geological Survey Techniques and Methods, vol. 6, article 240, 2008.

[25] M. Camporese, C. Paniconi, M. Putti, and S. Orlandini, "Surface-subsurface flow modeling with path-based runoff routing, boundary condition-based coupling, and assimilation of multisource observation data," Water Resources Research, vol. 46, no. 2, Article ID W02512, 2010.

[26] L. E. Condon and R. M. Maxwell, "Implementation of a linear optimization water allocation algorithm into a fully integrated physical hydrology model," Advances in Water Resources, vol. 60, pp. 135-147, 2013.

[27] G. Cheng, X. Li, W. Zhao et al., "Integrated study of the waterecosystem-economy in the Heihe River Basin," National Science Review, vol. 1, no. 3, pp. 413-428, 2014.

[28] X. Hu, H. Xiao, Y. Lan, J. Wang, and H. Ding, "Experimental study of calculating method of River Seepage in middle and upper reaches of the Heihe River," Journal of Glaciology and Geocryology, vol. 34, no. 2, pp. 460-468, 2012.

[29] M. Zhang, Systems Analysis and Optimal Allocation of Water Resources in the Middle Reaches of Heihe River, Northwest University, 2007.

[30] J. Zhou, B. X. Hu, G. Cheng, G. Wang, and X. Li, “Development of a three-dimensional watershed modelling system for water cycle in the middle part of the Heihe rivershed, in the west of China," Hydrological Processes, vol. 25, no. 12, pp. 1964-1978, 2011.

[31] X.-S. Wang, M.-G. Ma, X. Li, J. Zhao, P. Dong, and J. Zhou, "Groundwater response to leakage of surface water through a thick vadose zone in the middle reaches area of Heihe River Basin, in China," Hydrology and Earth System Sciences, vol. 14, no. 4, pp. 639-650, 2010.

[32] L.-T. Hu, C.-X. Chen, J. J. Jiao, and Z.-J. Wang, "Simulated groundwater interaction with rivers and springs in the Heihe river basin," Hydrological Processes, vol. 21, no. 20, pp. 27942806, 2007.

[33] B. Wu, Y. Zheng, X. Wu et al., "Optimizing water resources management in large river basins with integrated surface watergroundwater modeling: a surrogate-based approach," Water Resources Research, vol. 51, no. 4, pp. 2153-2173, 2015.

[34] Y. Yao, C. Zheng, J. Liu et al., "Conceptual and numerical models for groundwater flow in an arid inland river basin," Hydrological Processes, vol. 29, no. 6, pp. 1480-1492, 2015.

[35] Y. Tian, Y. Zheng, B. Wu, X. Wu, J. Liu, and C. Zheng, "Modeling surface water-groundwater interaction in arid and semi-arid 
regions with intensive agriculture," Environmental Modelling \& Software, vol. 63, pp. 170-184, 2015.

[36] X. Li, G. Cheng, S. Liu et al., "Heihe watershed allied telemetry experimental research (HiWater): scientific objectives and experimental design," Bulletin of the American Meteorological Society, vol. 94, no. 8, pp. 1145-1160, 2013.

[37] Y. Nian, X. Li, J. Zhou, and X. Hu, "Impact of land use change on water resource allocation in the middle reaches of the Heihe River Basin in northwestern China," Journal of Arid Land, vol. 6, no. 3, pp. 273-286, 2014.

[38] M. Hrachowitz, H. H. G. Savenije, G. Blöschl et al., "A decade of Predictions in Ungauged Basins (PUB)-a review," Hydrological Sciences Journal, vol. 58, no. 6, pp. 1198-1255, 2013.

[39] M. B. Cardenas, J. L. Wilson, and V. A. Zlotnik, "Impact of heterogeneity, bed forms, and stream curvature on subchannel hyporheic exchange," Water Resources Research, vol. 40, no. 8, pp. W083071-W0830713, 2004.

[40] Y. Chen, D. Zhang, Y. Sun, X. Liu, N. Wang, and H. H. G. Savenije, "Water demand management: a case study of the Heihe River Basin in China," Physics and Chemistry of the Earth, vol. 30, no. 6-7, pp. 408-419, 2005.

[41] Q. Feng, G. D. Cheng, and K. N. Endo, “Towards sustainable development of the environmentally degraded River Heihe basin, China," Hydrological Sciences Journal, vol. 46, no. 5, pp. 647-658, 2001.

[42] M. Matete and R. Hassan, "An ecological economics framework for assessing environmental flows: the case of inter-basin water transfers in Lesotho," Global and Planetary Change, vol. 47, no. 2-4, pp. 193-200, 2005.

[43] J. Wu, Y. Ding, B. Ye, Q. Yang, X. Zhang, and J. Wang, "Spatiotemporal variation of stable isotopes in precipitation in the Heihe River Basin, Northwestern China," Environmental Earth Sciences, vol. 61, no. 6, pp. 1123-1134, 2010.

[44] X. Li, L. Lu, G. Cheng, and H. Xiao, "Quantifying landscape structure of the Heihe River Basin, north-west China using FRAGSTATS," Journal of Arid Environments, vol. 48, no. 4, pp. 521-535, 2001.

[45] Z. Xiong and X. Yan, "Building a high-resolution regional climate model for the Heihe River Basin and simulating precipitation over this region," Chinese Science Bulletin, vol. 58, no. 36, pp. 4670-4678, 2013.

[46] H. Xi, Q. Feng, J. Si, Z. Chang, and S. Cao, "Impacts of river recharge on groundwater level and hydrochemistry in the lower reaches of Heihe River Watershed, northwestern China," Hydrogeology Journal, vol. 18, no. 3, pp. 791-801, 2010.

[47] J. Zhao, X. S. Wang, and L. Wan, "Runoff change and its simulation in main stream of heihe river at gaoya section," Journal of Desert Research, vol. 5, article 43, 2011.

[48] Z. Nan and L. Zhang, "Simulations of SWAT model under multiple scenarios in the upper and middle reaches of the Heihe River Basin (2011-2030)," Heihe Plan Science Data Center, 2014.

[49] H. R. Bureau, Long-Term Runoff Observation with Ten-Days Interval of Yingluoxia and Zhengyixia Gorges in Heihe River Basin, Heihe Plan Science Data Center, 2015.

[50] Y. Zheng, Heihe Plan Science Data Center, 2014.

[51] K. Pi, Study on the Laws of Infiltration in Heihe River and the Stochastic Simulation About River and Groundwater, Northwest University, 2015.

[52] J. E. Nash and J. V. Sutcliffe, "River flow forecasting through conceptual models part I-a discussion of principles," Journal of Hydrology, vol. 10, no. 3, pp. 282-290, 1970.
[53] Y. Yang and F. Tian, "Abrupt change of runoff and its major driving factors in Haihe River Catchment, China," Journal of Hydrology, vol. 374, no. 3-4, pp. 373-383, 2009.

[54] X. Hu, L. Lu, X. Li, J. Wang, and M. Guo, "Land use/cover change in the middle reaches of the Heihe River Basin over 2000-2011 and its implications for sustainable water resource management," PLoS ONE, vol. 10, no. 6, Article ID e0128960, 2015.

[55] X. Deng and C. Zhao, "Identification of water scarcity and providing solutions for adapting to climate changes in the Heihe River Basin of China," Advances in Meteorology, vol. 2015, Article ID 279173, 2015.

[56] C. Liu, J. Liu, Y. Hu, H. Wang, and C. Zheng, "Airborne thermal remote sensing for estimation of groundwater discharge to a River," Groundwater, 2015.

[57] Z. Xie, S. Liu, and Y. Zeng, Dataset of Estimation on Channel Section Flow and Stage in the Middle Reaches of the Heihe River Basin (1979-2014), Heihe Plan Science Data Center, 2015. 

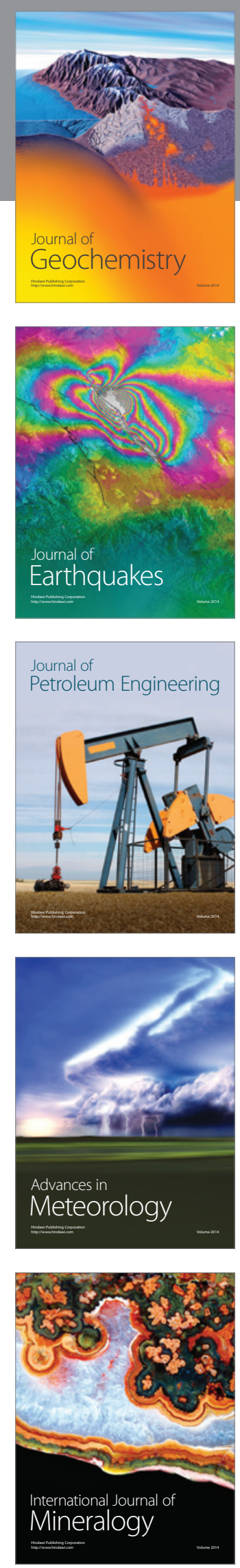
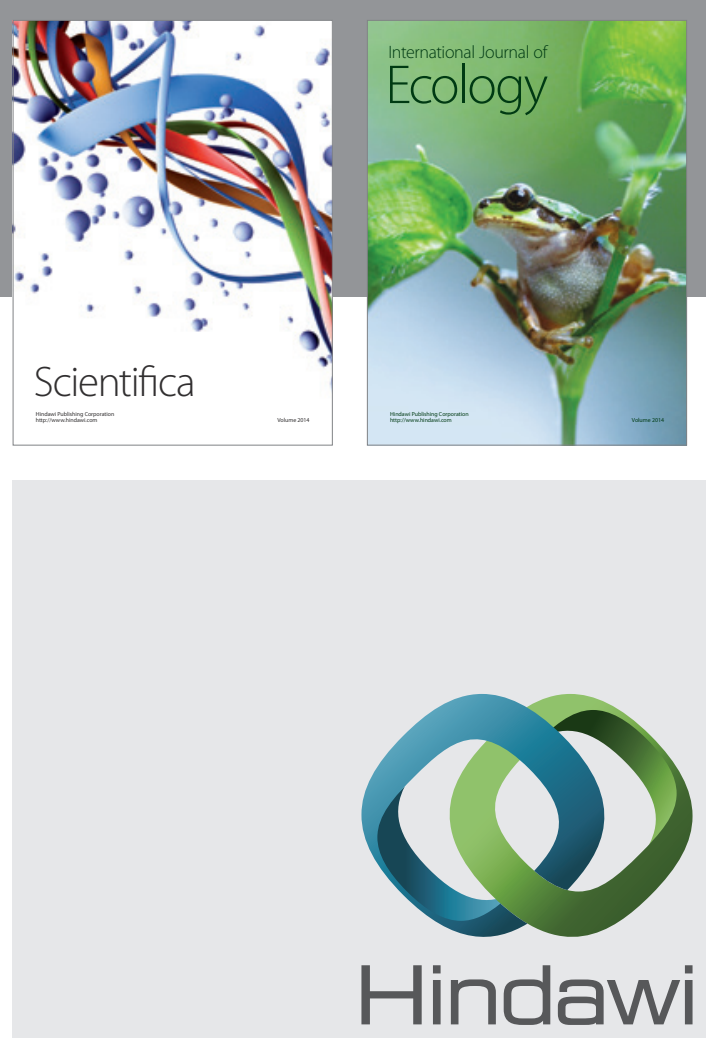

Submit your manuscripts at

http://www.hindawi.com
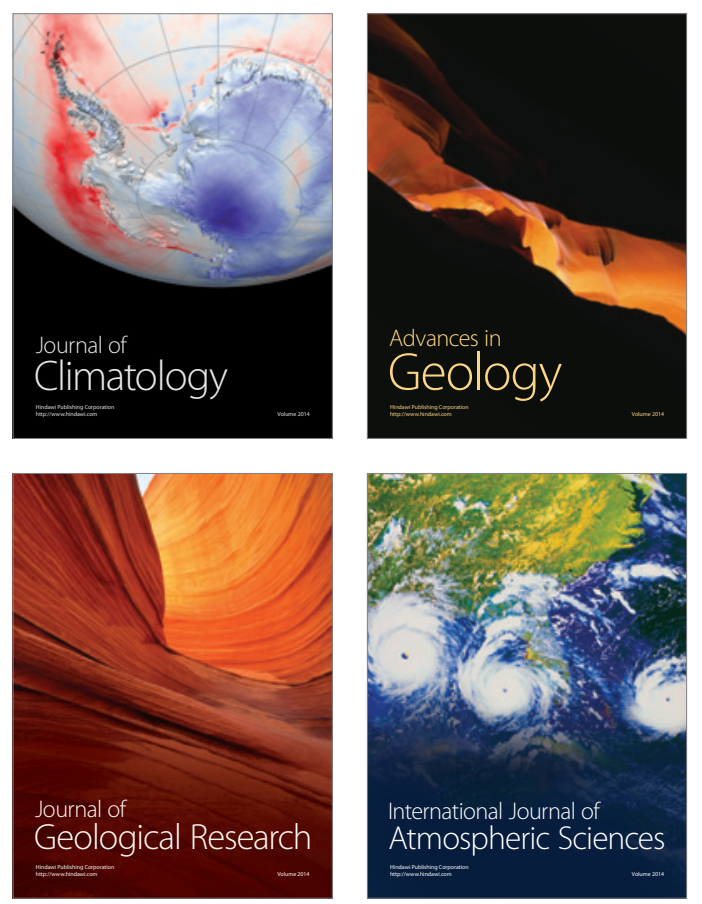

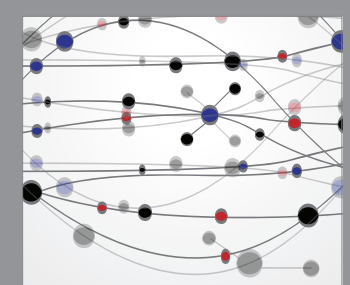

The Scientific

\section{World Journal}
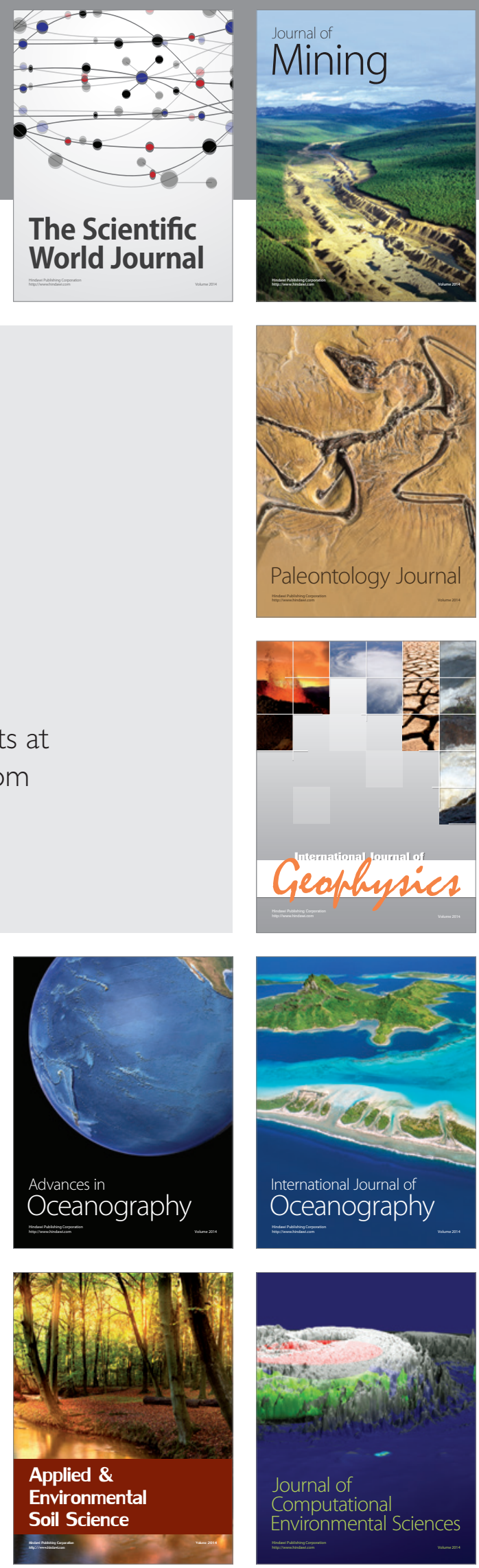